\title{
The Impact of Online Media on Second Language Acquisition by Polish Students
}

\author{
Artur Świątek \\ The Pedagogical University of Cracow, Cracow, Poland
}

\begin{abstract}
The objective of this paper will be a rather theoretical analysis concerning the unavoidable impact new online media (online texts, online tests, learning materials, films, music, and other potential stimuli) on L2 (second language) Polish students. We are living in the era of information which is quick, very frequently unimportant, but the one that must be necessarily distributed, because that is the only essence of human existence nowadays. Information that is conveyed concerns not only a native language, the comprehension of which is extremely simple, but, which is apparent, also a foreign language, where the comprehension needs lots of effort, recently facilitated by online resources, e.g., the Internet and social networking websites, namely Facebook, Twitter, etc.. In this paper, the author intends to demonstrate, via a questionnaire distributed among Polish students in different age and proficiency groups, the results of the research on the impact of online media on L2 acquisition by Polish students. The results will prove that this impact is significant, positive, and practical for Polish subjects.
\end{abstract}

Keywords: L1 (first language), L2 (second language), language acquisition, impact, online media

\section{Introduction}

The development of modern technology and its current aftermaths in the form of common technological devices, such as computers, I-pads, I-pods, tablets, and Wi-Fi connection provides lots of opportunities for L2 learners to grasp the language with all its nuances, puzzles, and complexities. Digital technology also offers a wide range of activities and chances to improve learners' linguistic skills than can immediately result from their access to the afore-mentioned devices. Do learners really take this evident opportunity for the sake of learning language? This question and the subsequent ones, posed below, need to be answered in this paper to find out whether modern technology really enhances learning a foreign language and facilities its acquisition. The author of the paper believes that it is possible. Let us find out whether his opinion in this respect may be proved by relevant research results and students' attitude to modern technology in general.

\section{Aims}

The aims of the paper are the following: (1) finding the answer to the question: "Is there a significant impact of online media on L2 acquisition compared to traditional classroom teaching?"; and (2) evaluating and discussing the questionnaire completed by L2 subjects.

Artur Świątek, Ph.D., Institute of Neo-philology, The Pedagogical University of Cracow. 


\section{The Impact of Computers on Learning English in Contrast to Other Offline Sources}

Computers offer a wide variety of opportunities to communicate with people all over the world. On the other hand, chat rooms foster human-to-human communication as a means for developing literacy and communication skills.

In a normal classroom setting, outgoing students will try new things in the target language. On the other hand, there exist some more timid students who do not like to be asked to interact and practise the language in traditional face-to-face conversation styles.

For example, while talking about ESL (English as a second language) students, Warchauer (1996) suggested that the background of certain ESL students may have an adverse effect on their ability or willingness to participate in face-to-face conversation. When learners are engaged online, the effects of the differences are minimalized, which is realized in even more active participation.

Even more timid learners can develop confidence when talking online. There is no face-to-face intimidation, and communication goals and experiences are being created.

With online communication, students have more time to think about and process the information given to them. Kelm (1992) found that because of the additional lag time between turns, users were afforded time to edit and reflect on the conversation at hand; hence, even usually non-participatory students became frequent contributors in online discussion.

Chat rooms allow time to process and internalize what is being said to prepare for future face-to-face contact. They also allow time for revision and reflection of the conversation and its various dimensions.

E-mail demonstrates a similar situation to that of chat rooms. Unlike chat rooms, students have additional time to read, process, and translate the material that was sent to them. With e-mails, learners are able to print the information in the target language and go back and look up unfamiliar vocabulary in the dictionary if necessary. E-mails can be used in classroom discussion and are an excellent way to introduce new, less formal vocabulary. There are also opportunities for e-pals which are an online email or a chat room friend.

\section{Meaning}

Meaning has to do with making input comprehensible and developing literacy.

The chat room provides an excellent opportunity to develop skills in reading and writing because of the nature of chat rooms, both reading and writing skills are essential.

In a chat room, we can observe one native speaker of the target language and one non-native speaker, the amount of comprehended input will be determined by the awareness of the native speaker to his/her non-native speaker counterpart.

If the native speaker of the target language realizes that the chat room partner is less fluent than himself, hopefully he will adjust his speech to adapt to the needs of the non-native speaker.

Either way however, by having to read and type in the chat room literacy skills are greatly increased and students become better readers and writers, not hearers and speakers only.

E-mails offer similar experiences while also providing additional time to read and understand the text. Students who receive e-mails can benefit each other by reading the e-mails out loud, like story-telling time. In this manner, the same literacy and input goals for meaning will be met. 
DVDs, on the other hand, seem to be the new genre emerging that will take meaning, use, and language to the next level. Though television and videos do not help in developing literacy skills, they do provide comprehensible input for the student.

Teachers need to be wise, tolerant, and skilful in choosing what kind of videos will be presented so that the text does not exceed the comprehension of the student. Being able to pick the appropriate video for the level of the students is a major advantage of the teacher.

Awareness of language, its forms and uses can be discovered when using computers in a classroom setting. Language that is taught in a classroom situation is more formal and stiff than everyday speech.

By using chat rooms and e-mails, additional language forms and uses can be introduced through basic conversations and in a specific context.

Computers can use language to generate new knowledge simply by the diverse vocabulary that will be used. New knowledge will emerge not only about language, but also about using computers and information systems in general as well.

By creating a multi-media approach to any particular language program, the instructor can be assured of exposing students to different learning techniques so that they are able to find one or a combination of several that work best for their own needs.

Videos allow more of an opportunity by being able to watch videos about these specific topics and then actually experimenting with them in the classroom.

Friends can be made while learning and practising in the target language. Students have the opportunity to be social without the face-to-face intimidation factor. Utilizing and manipulating information technology will only help the L2 learner and make the experience fun and exciting. No matter how much information technology is employed, nothing will ever replace the importance of practice in learning an L2.

Using the computer and television is simply aids that will foster interest in the language, not replace the need for experience in the language. Computers are helpful to aid the student who may not feel confident in his/her ability to perform in real-life experiences. By using chat rooms and e-mails, students are able to develop critical literacy skills while having additional time to internalize and review the conversation. Videos are effective because of the repetition involved.

Following language laboratories, computers and television became the two audiovisual technologies allowing everyone to have easy access to authentic language input for the enhancement of various language skills (Brinton \& Gaskill, 1987; Poon, 1992; Berber, 1997; Bell, 2003, among others).

Audiovisual technologies have been favored a lot in L2 acquisition, because they support a cognitive approach to language learning which allows learners' maximum opportunity to interact within rich contexts through which they construct and acquire L2 competence in the language.

For instance, computers can provide facilitative functions for both teachers and students through keeping with students' language needs, interests, and current curricula.

Teachers can quickly and easily provide the necessary language input through various audiovisual programs which trigger communication.

Research findings have proven that the use of audiovisual technology has a positive effect on the attainment of various language skills. 
The employment of various audiovisual technologies in SLA (Second Language Acquisition) has its own limitations and weaknesses which should also be considered.

By recognizing both the advantages and disadvantages of the application of various audiovisual technologies, the maximum effectiveness of technology to enhance SLA can be achieved.

\section{Advantages and Disadvantages of Miscellaneous Audiovisual Technologies on SLA}

According to Pemberton, Fallahkhair, and Masthoff (2004), interactive television allows some level of user interactivity, providing new facilities for information retrieval and communication.

Baker (1996) also focused on the pedagogical value of TV news in EFL (English as a Foreign Language) classes and listening comprehension. According to Baker, TV news can help EFL students improve their listening comprehension. Baker made some suggestions for incorporating TV news programs into language learning at all levels. The study concluded that, language learners at various proficiency levels approach TV news in the target language with differing objectives; for example, at the beginning, learners concentrate on listening skills and vocabulary building, whereas advanced learners focus on content and accuracy.

The current increasing application of various technologies such as computers in L2 acquisition confirms the pedagogical value of this technology.

Computers along with their attached language learning programs could provide L2 learners with more independence from classrooms and allow learners the option to work on their learning material at any time anywhere.

Once various audiovisual technologies are used in conjunction with traditional L2 classroom study, students can study more independently, leaving the teacher more time to concentrate effort on those parts of L2 teaching that are still hard or impossible by the technology such as essay writing and presentation.

Here is a list of some advantages attached to the application of various audiovisual technologies in L2 learning: (1) prove practices for students through the experiential learning; (2) offer students more the learning motivation; (3) enhance student achievement; (4) increase authentic materials for study; (5) encourage greater interaction between teachers and students and students and their peers; (6) emphasize the individual needs; (7) regard independence from a single source of information; (8) enlarge global understanding; (9) provide a lot of fun games and communicative activities; (10) reduce the learning stresses and anxieties; and (11) help L2 learners strengthen their linguistic skills through various communicative and interactive activities.

Audiovisual mass media technologies are pedagogically valuable source of language input mainly, because they: (1) provide the language learners with authentic materials; (2) motivate the language learners; (3) facilitate interaction which helps the development of communicative activities; and (4) provide opportunities for experiential learning.

There are also some disadvantages of using the below-mentioned technologies. They are as follows: lack of insufficient knowledge about the way, e.g., computers should be utilized may stop some language learners/teachers to use them.

As it results from the above lists of both advantages and disadvantages of using audiovisual technologies in teaching L2 to foreign students, a list of advantages definitely prevails. As for the list of disadvantages, the only problem is the appropriate application of the devices at hand with preserving a proper balance in the frequency of applying such devices to the recipients- $-\mathrm{L} 2$ students. 


\section{Research}

To find out how online media affect L2 acquisition of English by L2 Polish students, the following research questionnaire was distributed among students to complete, respond, and elicit information essential to comprehend the impact such media have on the respondents.

Research: Questionnaire

Please answer the questions below.

1. Which online media do you use to enhance/improve your English skills?
a. Facebook
b. Twitter
c. MySpace
d. computer games websites
e. Other

2. Do you think that it helped you perfect your English? If so, how? If not, why?

3. Have you ever used Facebook, Twitter, MySpace, or other online media in Polish?

a. Yes

b. No

c. Which other media did you use?

4. If so, why did you decide to use Polish instead of English?

5. What do you think, which of your skills improved thanks to using online media?

a. reading comprehension

b. listening comprehension

c. speaking

d. writing

6. Have you ever used an Interactive board while studying English?

a. Yes

b. No

7. If so, do you think it was useful or not?

\section{Research Group}

Fifty-four subjects participated in the study. The research group consisted of first-year English philology students (evening course), age: 20.8; experience in English: 9.3 years and intermediate foreign language school learners; age: 14.0; experience in English: 7.5 years.

\section{Findings}

The results, demonstrated in Tables 1-4, indicate the responses provided by the subjects to questions 1 , 3,5 , and 6 . The answers provided by the students representing different age groups differ significantly in case of using online media to improve their English skills (see Tables 1-4), but the difference is not so apparent in case of questions 2 and 5 .

Table 1

Question 1: Which Online Media Do You Use to Enhance/Improve Your English Skills?

\begin{tabular}{lllll}
\hline & Facebook (\%) & Twitter (\%) & Internet games (\%) & Other (\%) \\
\hline Intermediate foreign language school learners & 83 & 26 & 66 & 33 \\
First-year English philology students (evening course) & 66 & 0 & 25 & Less than 1 \\
\hline
\end{tabular}


Table 2

Question 3: Have You Ever Used Facebook, Twitter, or Other Online Media in Polish?

\begin{tabular}{lcc}
\hline & Yes (\%) & No (\%) \\
\hline Intermediate foreign language school learners & 94 & 6 \\
First-year English philology students (evening course) & 72 & 28 \\
\hline
\end{tabular}

Table 3

Question 5: What Do You Think, Which of Your English Skills Improved Thanks to Using Online Media?

\begin{tabular}{lllll}
\hline & $\begin{array}{l}\text { Reading comprehension } \\
(\%)\end{array}$ & $\begin{array}{l}\text { Listening comprehension } \\
(\%)\end{array}$ & $\begin{array}{l}\text { Speaking } \\
(\%)\end{array}$ & $\begin{array}{l}\text { Writing } \\
(\%)\end{array}$ \\
\hline Intermediate foreign language school learners & 77 & 50 & 55 & 72 \\
First-year English philology students (evening course) & 77 & 31 & 33 & 47 \\
\hline
\end{tabular}

Table 4

Question 6: Have You Ever Used an Interactive Board While Studying English?

\begin{tabular}{lcc}
\hline & Yes (\%) & No (\%) \\
\hline Intermediate foreign language school learners & 88 & 12 \\
First-year English philology students (evening course) & 1 & 99 \\
\hline
\end{tabular}

This part of research demonstrates the remaining percentage of responses provided by the subjects. They are not presented in a tabular form, as above, due to many miscellaneous answers the students provided. Such a form of presenting findings is, according to the author of this paper, more logical and ensures more relevant background to draw conclusions from the conducted study. The answers are grouped in accordance with two different age groups and the frequency of responses the recipients were so kind to provide.

(1) Intermediate foreign language school learners

Question 1: Remaining answers: (a) You Tube-33\%; (b) Google websearch-11\%; and (c) Skype, games in English, films with Polish subtitles, NBA.com-below 1\%

Question 2: The most common answers: Using English online media as helpful in perfecting learners' English.

Question 7: The most common answers: Using an interactive board while studying English considered useful and practical.

(2) English philology subjects

Question 1: Remaining answers: Google websearch, e-books in English, websites with articles online, BBC (British Broadcasting Corporation) World, CNN (Cable News Network), BBC News, English Club, English translator, Yahoo, Skype, Discovery Science, sport websites, BBC Radio One, Four, New York Times, BBC Learning English, and You Tube-below $1 \%$.

Question 2: The most common answers: Using English online media as an excellent tool to master communication skills.

Question 7: The most common answers: Due to being unfamiliar with the use of such a device, the answers were not provided. 


\section{Conclusions and Implications for Future Studies}

After having applied the research questionnaire and calculating the results we have observed the significant, practical, and positive impact of English online media on L2 acquisition by Polish students. It can be proved by the findings from previous studies and results of the researcher's questionnaire. The following conclusions may be listed below: (1) students' positive answers; (2) satisfaction of the subjects' with the use of English online media; (3) enhancing all skills; (4) improving communication; (5) facilitating social interaction; and (6) being more aware of English culture and people.

\section{Suggestions for the Future Study and Pedagogical Implications}

We may suggest the following practical and pedagogical implications to enhance better acquisition of English by L2 Polish subjects by means of online media: (1) further monitoring of the use of English online media by Polish L2 students; and (2) maintaining appropriate equilibrium between traditional "board teaching" and technology-assisted teaching.

\section{References}

Baker, N. (1996). Using the TV news in the EFL classroom. Zielsprache, 26(2), 30-33.

Bell, D. M. (2003). TV news in the EFL/ESL Classroom: Criteria for selection. TESL-EJ, 7(3), 1-17. Retrieved from http://www-writing.berkeley.edu/TESL-EJ/ej27/a2.html

Berber, S. A. (1997). Proficiency and comprehension of television news in a foreign language. Revista de Documentacao de Estudos em Linguistica Teorica e Aplicada (D.E.L.T.A.), 13(2), 177-190.

Brinton, D., \& Gaskill, W. (1987). Using news broadcasts in the ESL/EFL classroom. TESOL Quarterly, 12(4), 403-413.

Kelm, O. (1992). The use of synchronous computer networks in second language instruction: A preliminary report. Foreign Languages Annals, 25, 441-454.

Pemberton, L., Fallahkhair, S., \& Masthoff, G. (2004). Toward a theoretical framework for informal language learning via interactive television. CELDA Journal, IADIS International Conference Cognition and Exploratory Learning in Digital Age, Lisbon, Portugal.

Poon, A. (1992). Action research: A study on using TV news to improve listening proficiency. Research Report, 14, 1-70.

Warchauer, M. (1996). Comparing face-to-face and electronic discussion in the second language classroom. CALICO Journal, 13, $7-26$. 